\title{
COMPARING GENETIC PARAMETERS OF FRIESIAN MILK PRODUCTION TRAITS IN COMMERCIAL AND STATE FARMS IN EGYPT
}

\author{
SANAD, SAFAA S. and A. A. AFIFY \\ Animal production research Institute - Ministry of Agriculture, Cairo, Egypt
}

(Manuscript received 26 September 2016)

\begin{abstract}
$\mathrm{T}$

his study was conducted to estimate the genetic parameters for milk production traits of Friesian cattle in two selected dairy farms located in the Nile Delta of Egypt. A total of 1438 lactation records during the years2001 to 2009 were collected to represent 472 cows in Sakha Governmentfarm (SF). In comparison, a total of 1660 lactation records during the years 1998 to 2005 were collected to represent 465 cows in Gharbawy commercial (GF) farm. The derivative-free restricted maximum likelihood (REML) procedure was used to determine heritability, genetic correlation and breeding value of the studied traits. The results indicated that non genetic factors affecting lactation period (LP), total milk yield (TMY) and 305d -milk yield (305 d-MY) had highly significant $(p<0.001)$ effect on those traits except the effect of season of calving on TMY. Interaction between (herd \& parity) and the interaction between (herd \& parity \& season) had highly significant effect $(P<0.001)$ on all milk production traits. The overall means of LP, TMY and 305-dMY were 313 day; $4140 \mathrm{~kg}$; $3630 \mathrm{~kg}$, respectively for cows in SF and as the corresponding values in GFwere 369.5 day, $8820 \mathrm{Kg}$ and $7430 \mathrm{~kg}$. Estimates of direct heritability for LP, TMY, and 305MY in SF were 0.10, 0.11and 0.19 respectively, the corresponding estimates for GF were 0.10 , 0.13 and 0.07 respectively on the other hand, estimates of maternal heritability for LP,TMY and 305MY in SF were $0.04,0.07$ and 0.06 , respectively, while, the estimate in GF were $0.08,0.09$ and 0.12 , respectively. The breeding values of sires estimated for LP,TMY and 305d-MY were 50.4, 27.4 and 42.3, respectively in SF, while the same estimates in GF were150.1, 20.04, and 30.7. The breeding values of cow concerning LP, TMY and 305MY in SF were $63.32,45,4$ and 21.5 while in GF, values were $195.1,29.9,53.2$, respectively. It can be concluded that improving environmental conditions and management practices, coupled with improved genetic potential of dairy animals in the state or commercial farms would be more effective approaches for high milk productivity.
\end{abstract}

\section{INTRODUCTION}

Friesians are the most reputed dairy cattle in Egypt. In livestock population under computerized recording system, a large size of phenotypic observations is available at low cost and it is worthwhile to use them in estimation of genetic parameters for economic traits. Milk production in dairy farms can be increased either 
by increasing the number of milking animals or upgrading milk productivity per animal through improving the environmental conditions, managerial practices, and genetics. There are various mating systems to improve genetic potential of the dairy animals. Heritability is the keys genetic parameter which determines with other factors the amount of possible genetic progress for selected traits.(Usman et al ,2012)

Development of milk production in Egypt depends largely on establishment of modern and large commercial dairy farms. These farms in turn, depend on high technology operation, skilled labor and high producer dairy cattle. The government and the private sector imported large numbers of purebred dairy cattle. Particularly Friesian.(Amr, 2013). The aim of the animal breeding plans is not only to produce superior individual animals but also to cause a general improvement in a herd by selecting genetically superior sires and dams as parents for future generations. Quantitative genetics has a large applicability in animal husbandry. The main goal in animal breeding is to select those cows, which can produce offspring with improved phenotypes. In order to establish effective breeding programs it is necessary to recognize the genetic inheritance of a certain genetic characters (Bugeac et al., 2013).

There is no doubt that performance of governmental and commercial farms differs relatively due to many reasons such as capital assets, managerial practices ding, breeding plans ...etc.

In this concern, appraisal of dairy farm profitability and evaluation of productivity through milk traits become important to improve the production efficiency.

Therefore, this study was carried out to compare efficiency of milk production in two farms, one of them is governmental and the other is commercial. The scientific basis of comparison was to investigate genetic and non-genetic factors affecting milk yield in both farm. Also, breeding value of cows sires and dams for the assigned milk traits were considered.

\section{MATERIALS AND METHODS}

The present study was conducted to determine genetic and phenotypic parameters that effect milk production traits of Friesian cattle in two selected dairy herds in the Nile delta of Egypt .

A total of 1438 lactation records during the years 2001 to 2009 were collected to represent 472 cows (daughters of 318 dams and 52 sires) in Sakha Experimental farm (SF) located in Kafr EL-Shaikh Governorate. In comparison, a total of 1660 
lactation records during the years 1998 to 2005 were collected to represent 465 cows (daughters of 426 dams and 170 sires) in Gharbawy commercial farm (GF) located in El-Sharkia Governorate.

Animal nutrition in SF depends on concentrate feed mixture along with rice straw in addition to Egyptian clove in winter or clover hay during summer (May to November). On the other hand, cows in GF were feed on corn silage, wheat straws and concentrate feed mixture in addition to the Egyptian clover in winter or clover hay in summer. In both farms SF and GF, cows producing more than $10 \mathrm{~kg}$ of milk or cows at late pregnancy period were offered extra CFM.

As a common practice, milking cows were subjected to machine milking twice a day in SF and 4 times per day in GF. In both herds, cows were artificially inseminated by reaching the 2 nd month post partum. Heifers in both farms were served when reaching 18 month of age or $305 \mathrm{~kg}$ of live body weight.

\section{Statistical analysis:}

Data were analyzed using the general linear model (GLM) procedure (SAS 2003). The following statistical mixed model wasused:

$Y_{i m j k l}=\mu+S_{i}+h_{m}+P_{j}+S E_{k}+Y_{l}+(h * P)_{m j}+(h * S E)_{m k}+(h * P * S E)_{m i j}+e_{i m j k l n}$ where,

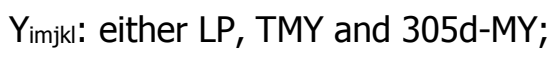

$\mu$ : an underlying constant specific to each trait; $S_{i}$ : a random effect of $i$ th sire; $h m$ the fixed effect of $m^{\text {th }}$ herd $P_{j}$ : the fixed effect of $j^{\text {th }}$ parity of calving; $S E_{k}$ :the fixed effect of $k^{\text {th }}$ season of calving; $Y_{1}$ : the fixed effect of $t^{\text {th }}$ year of calving , $(h * P)_{m j}=$ The interaction between $m^{\text {th }}$ effect of herd and $j^{\text {th }}$ effect of parity . $(h * S E)_{m k}=$ The interaction between $m^{\text {th }}$ effect of herd andk ${ }^{\text {th }}$ effect of season . $(h * P * S E)_{m i j}=$ The interaction between $m^{\text {th }}$ effect of herd, $j^{\text {th }}$ effect of parityand $k^{\text {th }}$ effect of season .andeimjkl $=$ random residual assumed to be independent normally distributed with mean zero and variance $\sigma^{2} e$.

Heritability, genetic correlations and breeding values of studied traits were estimated with derivative-free restricted maximum likelihood(REML) procedures using the MTDFREML program of Boldman et al., (1995). The assumed model was:

$y=X b+Z_{1} a+Z_{2} m+Z_{3} p+e$,

$\operatorname{Cov}(a, m)=A \sigma_{a, m}$

where,

$y$ : a vector of observations, $b$ : a vector of fixed effect, $a, m, p$ and e are the vectors of direct additive genetic effect, maternal genetic effect, permanent environmental 
effect and the residual effect, respectively, $X, Z_{1}, Z_{2}$ and $Z_{3}$ are incidence matrix relating individual records to $b, a, m$ and $p$, respectively.

Table 1. Distribution of cows and lactation records in Sakha and Ghrbawy herds.

\begin{tabular}{|ccc|}
\hline Observation & Sakha herd & Ghrbawy herd \\
\hline No of records & 1438 & 1660 \\
No of sires & 52 & 170 \\
No of dams & 318 & 426 \\
No of cows & 472 & 465 \\
\hline
\end{tabular}

\section{RESULTS AND DISCUSSION}

As shown in table (2), coefficients of variability (CV) for all studied milk traits were considerably higher in SF than that in GF, the higher estimates of $\mathrm{CV} \%$ in SF may reflect a great variation of milk traits among individuals which enhance the possibility of utilizing such variation to improve milk productivity of Friesian cows., The average TMY and 305d-MY in GF were greater by $113.0 \%$ and $104.7 \%$ than that in SF, respectively this finding indicate superiority of milk productivity of GF cows as purebred imported herd in the commercial farm .

The lactation period (LP) for Holstein cows in Egypt was found to vary from 286 to 407 days and the coefficient of variability of lactation period ranged from 5 to $31.74 \%$ as mentioned by Hammoud (2013), and Faid (2015) in Egypt, respectively . The average of LP in the present study lies within the range of the above mentioned studies.

Table 2. Means, standard deviations (SD) and coefficients of variation (CV\%) for lactation period (LP), total milk yield (TMY)and305-day MY of Friesian cows in Sakha and Ghrbawy herds

\begin{tabular}{|c|cccc|cccc|}
\hline Trait & \multicolumn{4}{|c|}{ Sakha herd (SF) } & \multicolumn{4}{c|}{ Ghrbawy herd (GF) } \\
\hline & $\mathrm{N}$ & Mean & SE & CV\% & N & Mean & SE & CV\% \\
LP (day) & 1438 & 312.97 & 3.1 & 37.86 & 1660 & 369.52 & 2.4 & 26.70 \\
TMY (kg) & 1438 & 4140 & 41.7 & 38.16 & 1660 & 8820 & 66.1 & 30.50 \\
305d MY (kg) & 1438 & 3630 & 32.5 & 33.88 & 1660 & 7430 & 43.7 & 23.96 \\
\hline
\end{tabular}

Non genetic factors affecting milk production traits analysis of variance for factors affecting milk production traits under study in presented in table (3). Least square means (LSM) and standard errors (S.E) for factors affecting LP,305d-MY and TMY are shown in table (4) . 
The ANOVA results for the studied traits are give in table (3) it can be concluded that herd had significant effect on all milk production traits under study .

Table 3. Analysis of variance for milk production traits affected by management practices under study .

\begin{tabular}{|ccccc|}
\hline Source of variation & df & \multicolumn{3}{c|}{ Mean Squares } \\
\cline { 3 - 5 } & & LP & 305d-MY & TMY \\
\hline Sire & 217 & $15266.8^{* * *}$ & $5836476^{* * *}$ & $13354333^{* * *}$ \\
Herd & 1 & $95606.5^{* *}$ & $204540670^{* * *}$ & $468374645^{* * *}$ \\
Parity & 5 & $74226.2^{* * *}$ & $60425644^{* * *}$ & $30263873^{* * *}$ \\
Season & $51884.9^{* *}$ & $14211514 * * *$ & $18475158^{* * *}$ \\
Year & 11 & $231343.4^{* * *}$ & $24476946 * * *$ & $108778727^{* * *}$ \\
herd * parity & 5 & $45763.5^{* * *}$ & $4831086^{*}$ & $14536320^{* * *}$ \\
herd * season & 3 & $54849.0^{* * *}$ & $2278026^{\text {n.s }}$ & $6846670^{\text {n.s }}$ \\
herd * parity *season & 30 & $21071.9^{* * *}$ & $5540663^{* * *}$ & $6716290^{* *}$ \\
Residual & 2822 & 10029.9 & 2336762 & 3485239 \\
\hline
\end{tabular}

$*$ significant at $\mathrm{P}<0.05, * *=$ significant at $\mathrm{P}<0.01$, *** $=$ significant at $\mathrm{P}<0.001$, ns $=$ non significant

Table 3 shows that the effect of herd, parity, season and year of calving had highly significant effect $(P<0.001)$ on all milk production traits under study as reported previously table (3) .

Interaction between (herd\& parity) and the interaction between (herd \&parity \&season) had highly significant effect $(P<0.001)$ on all milk production traits .

Except interaction between(herd \& season)had non-significant effect for each of the 305-day MY and TMY .The differences among herds may be due to the differences, environmental condition and management practices in each farm and different herd size among farms. The same results were agreed with those obtained by Hammami et al. (2008) and Amr (2013) reported that farm had a highly significant effect on milk production traits .Gabr(2005) recorded that highly significant effect of herd on total milk yield and 305 day milk yield. These differences among farms may be due to the difference in genetic constitution among herds, management practices applied and the different environmental and climatic conditions due to different regions that affect adaptation of the cows.

Table (4) display the effects of parity, season of calving, year of calving and the farm on LP, TMY and 305d-MY. the result clarified highly significant $(P<0.01)$ effects of the aforementioned factors on all studied milk traits. The LP tended to increase with advancement of parity up to the $4^{\text {thl }}$ lactation period then declined thereafter. Mean

while, LP was longer in winter and spring compared with summer and autumn. This result indicates that adjustment of LP to 305-dayMY was practically out of control particularly in SF that reached 378.5 days of LP. Wide variation was noticed among years of calving for LP. As a similar trend, TMY tended to increase from $6015.9 \mathrm{~kg} \pm$ $139.5 \mathrm{in}$ the $1^{\text {st }}$ parity to $6910.4+160.9 \mathrm{~kg}$ in the $4^{\text {th }}$ parity and declined thereafter 
whereas $305 \mathrm{MY}$ tended to increase from $5111.9+99.4 \mathrm{~kg}$ in the $1^{\text {st }}$ parity to 5699.1 \pm 103.1 in the $3^{\text {rd }}$ parity.

Both averages of TMY and 305d- MY were higher for cows calved in winter and spring than in autumn and summer. This finding points to the importance of green fodder season in improving milk productivity. Estimates of TMY and 305MY recorded within years of calving showed increased pattern from 1998 up to 2003 then fluctuated until 2009. The rates of increase in TMY and 305day-MY for this period were $100.1 \%$ and $39.2 \%$, respectively. The rate of increase in TMY and 305d-MY for SF was $37.4 \%$ and $20.7 \%$ during 2001-2004, the corresponding values in GF was $120.3 \%$ and $41.2 \%$, respectively during $1998-2003$. This result proved a significant effect of year of calving on milk traits and acceleration of milk production in GF within the period 1998-2003. Hammoud (2013) came to the same result for 305 MY. The same result was found for LP.

The averages of LP for Friesian cows in Egypt were recorded to be 314,327 ,332 and 357 days as reported by Allam (2011) , Taha (2013) , Faid (2015) and ElAttar (2009), respectively. The averages of TMY for Friesian cows in Egypt were recorded to be 5387.0, 4348.0, 7208.7 and $9710 \mathrm{~kg}$ as reported by Taha (2013), Allam (2011), Faid (2015) and El-Attar (2009), respectively. The averages of $305 \mathrm{MY}$ for Friesian cows in Egypt were recorded to be4229, 5387, 6384.9 and $8366 \mathrm{~kg}$ as reported by Allam (2011), Taha (2013), Faid (2015) and El-Attar (2009), respectively. The difference in milk traits among different authors may be attributed to genetic potentiality of the different herds or referring to management practices and variability of climatic changes. Gabr (2005) observed that the differences in TMY and 305dayMYbetween parities were highly significant while no significant effect of parity on LP was found. On contrary, El-Attar(2009) and Allam(2011) found that parity had a highly significant effect on LP.

Lakshmi et al. (2009) explained that cows calved in fall and winter had comparatively low LP due to better feeding of cows that led to early conception and on time subsequent calving whereas, the probable reason for longer LP may be missing heats, improper timely insemination and repeat breeding.

In agreement with the present study, Usman et al. (2011) detected higher TMY in spring and lower TMY in summer. Abdel-Gader et al. (2007) reported that milk production was higher in winter than the other seasons. Javedet al. (2004) reported that milk production was higher in autumn and spring seasons and lower in hot summer. Similar results were obtained by Abdel-Gaderet al (2007), El-Attar (2009) and Allam (2011) who found that year of calving had significant effect on TMY and 305d-MY. Also, Mustafa and Serdar (2009) noticed that year of calving had significant effect on LP for Holstein cow . 
Table 4. Least square means (LSM) and standard error(SE) for milk traits in Friesian cows as affected by parity, season of calving, year of calving and herd on milk traits.

\begin{tabular}{|c|c|c|c|c|}
\hline dependent variable & NO & $\mathrm{LP} \pm \mathrm{SE}, \mathrm{d}$ & $\mathrm{TMY} \pm \mathrm{SE}, \mathrm{kg}$ & 305d-MY $\pm S E, k g$ \\
\hline \multicolumn{5}{|l|}{ Parity } \\
\hline 1 & 857 & $339.98 \pm 7.11$ & $6015.94 \pm 139.56$ & $5111.86 \pm 99.4$ \\
\hline 2 & 661 & $331.62 \pm 7.4$ & $6377.33 \pm 145.6$ & $5500.43 \pm 103.7$ \\
\hline 3 & 649 & $344.77 \pm 7.4$ & $6745.45 \pm 144.7$ & $5699.13 \pm 103.1$ \\
\hline 4 & 415 & $365.23 \pm 8.2$ & $6910.37 \pm 160.9$ & $5671.3 \pm 114.6$ \\
\hline 5 & 249 & $343.36 \pm 9.2$ & $6421.19 \pm 180.4$ & $5331.4 \pm 128.5$ \\
\hline 6 & 267 & $310.9 \pm 10.1$ & $5507.73 \pm 198.8$ & $4640.9 \pm 141.7$ \\
\hline Significant & & $* * *$ & $* * *$ & $* * *$ \\
\hline \multicolumn{5}{|l|}{ Season of calving } \\
\hline Autumn & 1021 & $328.08 \pm 7.1$ & ك & $5293.14 \pm 99.1$ \\
\hline Winter & 1056 & $343.05 \pm 7.3$ & $6476.64 \pm 141.5$ & $5406.98 \pm 100.8$ \\
\hline Spring & 526 & $356.77 \pm 7.9$ & $6464.2 \pm 154.1$ & $5352.71 \pm 109.8$ \\
\hline Summer & 495 & $329.39 \pm 7.7$ & $6153.47 \pm 154.4$ & $5250.53 \pm 109.9$ \\
\hline Significant & & $* * * *$ & $* * *$ & $* * *$ \\
\hline \multicolumn{5}{|l|}{ Year of calving } \\
\hline $\begin{array}{l}1998 \\
1999 \\
2000 \\
2001 \\
2002\end{array}$ & $\begin{array}{l}198 \\
224 \\
245 \\
397 \\
347\end{array}$ & $\begin{array}{l}222.72 \pm 11.94 \\
297.74 \pm 10.49 \\
321.16 \pm 10.18 \\
336.39 \pm 8.65 \\
360.17 \pm 8.79\end{array}$ & $\begin{array}{l}3946.57 \pm 234.4 \\
5771.0 \pm 205.8 \\
6192.1 \pm 199.8 \\
6406.8 \pm 169.7 \\
6935.75 \pm 172.7\end{array}$ & $\begin{array}{l}4186.51 \pm 167.0 \\
5313.8 \pm 146.6 \\
5350.80 \pm 142.3 \\
5348.38 \pm 120.9 \\
5518.78 \pm 123.0\end{array}$ \\
\hline 2003 & 329 & $402.42 \pm 9.0$ & $7896.15 \pm 176.7$ & $5826.65 \pm 125.9$ \\
\hline 2004 & 330 & $329.66 \pm 8.9$ & $6611.64 \pm 174.9$ & $5524.18 \pm 124.6$ \\
\hline 2005 & 340 & $385.61 \pm 10.5$ & $6239.25 \pm 177.4$ & $5354.11 \pm 126.4$ \\
\hline $\begin{array}{l}2006 \\
2007 \\
2008\end{array}$ & $\begin{array}{l}178 \\
153 \\
170\end{array}$ & $\begin{array}{l}369.43 \pm 11.9 \\
374.58 \pm 10.5 \\
329.14 \pm 10.9\end{array}$ & $\begin{array}{l}6748.67 \pm 206.4 \\
6596.32 \pm 234.0 \\
6471.51 \pm 206.7\end{array}$ & $\begin{array}{l}5449.8 \pm 147.1 \\
5503.35 \pm 166.7 \\
5306.5 \pm 147.3\end{array}$ \\
\hline $\begin{array}{l}2009 \\
\text { Significant }\end{array}$ & 187 & $\begin{array}{l}342.85 \pm 9.0 \\
* * *\end{array}$ & $\begin{array}{l}6140.1 \pm 213.7 \\
* * *\end{array}$ & $\begin{array}{l}5227.06 \pm 152.3 \\
* * *\end{array}$ \\
\hline \multicolumn{5}{|l|}{ Farm } \\
\hline GF & 1660 & $378.52 \mathrm{a} \pm 6.5$ & $8493.61 a \pm 126.9$ & $7093.87 a \pm 90.5$ \\
\hline SF & 1438 & $300.2 b \pm 16.8$ & $4165.69 b \pm 329.2$ & $3557.8 b \pm 234.6$ \\
\hline Significant & & $* * * *$ & $* * *$ & $* * *$ \\
\hline
\end{tabular}

$* * *$ highly significant $(\mathrm{p}<0.01)$; n.s not significant $(\mathrm{p}<0.05)$

\section{Heritability and the variance component estimates}

Table (5) summarize results of milk traits analysis with respect to additive genetic and phenotypic variances as well as heritability estimates. The variance components were estimated after identification of the non-genetic factors affecting milk traits. Direct $h^{2}$ estimates for milk were similar in both farms except $h^{2}$ estimate of $305 d-M Y$ that was relatively greater in SF (0.19) than that in GF (0.07). 
This finding may be attributed to available breeding plan in SF that permits continuous selection and culling of low producer cows.

Maternal $h^{2}$ estimate of milk traits were considerably less than direct $h^{2}$ estimates except maternal $h^{2}$ of $305 d-M Y$ that was higher in GF $(0.12)$ than its direct $h^{2}$ value. This result may indicate the genetic effect of sires on milk traits in both herds.

Generally, summation of direct and maternal $h^{2}$ indicated higher estimates for LP and TMY in GF as compared with SF while lower estimate for 305d-MY was detected in GF.

The results in Table 5. showed that the genetic correlation between LP, TMY and 305d-MY was positive in Sakha farm whereas the genetic correlation between LP ,TMY and 305 MY was negative in Ghrbawy farm.Also, maternal genetic correlation among milk traits studied were in most cases negative and small. Similar results are reported by Usman et al. (2011) and Mostafa et al (2013).

Table 5. Genotypic, environmental and phenotypic variance, covariance and heritability of productive traits of Friesian cows in Sakha and Ghrbawy herds.

\begin{tabular}{|c|c|c|c|c|c|c|}
\hline \multicolumn{4}{|c|}{ Sakha farm(SF) } & \multicolumn{3}{|c|}{ Ghrbawy farm.(GF) } \\
\hline & LP & TMY & 305-dMY & LP & TMY & 305-dMY \\
\hline$V_{a}$ & 60540 & 205570 & 346220 & 60520 & 238250 & 314000 \\
\hline Vam & 8950 & 117200 & 111790 & 500 & -18670 & -140050 \\
\hline $\mathrm{Vm}$ & 23770 & 127390 & 105570 & 50690 & 171940 & 566750 \\
\hline$V_{p e}$ & 724 & 16483 & 1805 & 1823 & 50549 & 22165 \\
\hline Vte & 500000 & 1448270 & 1249070 & 50000 & 1377020 & 3954740 \\
\hline$V_{p}$ & 593990 & 1914910 & 1814450 & 613530 & 1819080 & 1814450 \\
\hline$h^{2} a$ & 0.10 & 0.11 & 0.19 & 0.10 & 0.13 & 0.07 \\
\hline$h^{2} m$ & 0.04 & 0.07 & 0.06 & 0.08 & 0.09 & 0.12 \\
\hline \multicolumn{7}{|c|}{ Phenotype (above) and genetic (below) the diagonal covariance } \\
\hline & LP & TMY & 305 & LP & TMY & 305 \\
\hline $\begin{array}{l}\text { LP } \\
\text { TMY }\end{array}$ & 93740 & 275990 & $\begin{array}{l}343320 \\
655950\end{array}$ & 98920 & 341420 & $\begin{array}{l}-310620 \\
0697660\end{array}$ \\
\hline 305 & 23610 & 12265 & & -1650 & -33870 & \\
\hline \multicolumn{7}{|c|}{ phenotypic (above diagonal) and genetic correlation between milk traits (below diagonal) } \\
\hline & LP & TMY & 305-dMY & LP & TMY & 305-dMY \\
\hline LP & & 0.26 & 0.33 & & 0.32 & 0.18 \\
\hline TMY & 0.84 & & 0.35 & 0.82 & & 0.24 \\
\hline 305d-MY & 0.16 & 0.46 & & -0.01 & -0.12 & \\
\hline
\end{tabular}

$\mathrm{Va}=$ additive genetic effect, $\mathrm{Vam}=$ covariance between direct and maternal genetic effect, $\mathrm{Vm}=$ maternal genetic effect, $V p e=$ permanent environmental effect, $V e=$ environmental effect, $V p=$ phenotypic variance.$h^{2}$ adirect heritability for $L P, T M Y$ and $305 d-M Y$, respectively, while, $h^{2} m$ are maternal heritabilityfor LP, TMY and 305d MY, respectively, 
Low heritability estimates for LP indicate that this trait is affected mainly by environmental factors through improving feeding and managerial strategy procedures .Similar result were report by Mostafa et al. 2013 and Hommoud, 2013.

The differences in the estimated heritability in the present study due to herd and environmental conditions as well as the method of estimation. The low estimate indicated that the variation due to additive gene action was small and that the variation due to the environmental factor was important.

\section{Breeding values:}

Estimates of breeding values of cows, dams and sires for LP, TMY and 305d-MY are presented in Tables 6, 7and 8. The breeding values for LP, TMY and 305d-MYof cows ranged between 49.9 and -31.4 days, 15.7 and $-29.7 \mathrm{~kg}, 8,6$ and $-12.9 \mathrm{~kg}$, respectively in SF while it ranged between 130.1 and -65.0 days, 17.0 and $-12.9 \mathrm{~kg}$, 15.8 and $-37.4 \mathrm{~kg}$, respectively in GF. The ranges of breeding values for cows were higher than those for dams or sires for all traits. The results indicated that the range estimates for LP were considerably higher than that for TMY or 305d-MY and it were relatively greater for LP in GF than in SF. This finding cleared a wide variability in LP that can be controlled by proper management in order to optimize milk productivity of cows.

The range of cow breeding values for LP 63.32 days in SF and 195.12 days in GF (Table 6) is greater than 24.2 days reported by Afifi et al. (2002).This leads to state that selecting cows for milk production traits of the study according to the cow breeding values would be more reasonable and efficient than selecting them according to their sires or dams breeding values .

The range values either estimated by cows, sires or dams pathways for 305d-MY were wider than that estimated for TMY except that range estimated by cows in SF. Mean while, the maximum breeding values that estimated either by cows or sires for TMY were relatively higher than that for $305 \mathrm{~d}-\mathrm{MY}$. The maximum breeding values that estimated by dams did not give a reasonable results for milk traits. However, comparing the maximum breeding values of sires showed higher values attained by SF sires than those attained by GF for milk traits.

The range estimates for milk production either estimated by sires or dams in SF were greater than its correspondence in GF. On the other hand, the range values estimated by cows for TMY in SF were higher than in GF despite opposite trend was observed for 305d-MY.

In consequence, it could be stated that selecting cows in both farms for milk production traits according to cow breeding values concomitant with selecting them according to their sires would be more reliable and efficient.

The high range of breeding values of dams and cows compared to those of sires may be due to using few numbers of proven sires compared to using large 
number of dam and cows and thus makes a good media for selection in dams and cows . In addition, selection of dams for the next generation would lead to higher genetic improvement in the herd . The same trends were obtained by El-Attar (2009); Allam (2011) and Hammoud (2013) .

Table 6 . The predicted all Cows breeding values (CBV) for milk traits in Friesian cows in Sakha and Ghrbawy herds.

\begin{tabular}{|c|c|c|c|c|c|c|}
\hline & \multicolumn{3}{|c|}{ SF } & \multicolumn{3}{|c|}{ GF } \\
\hline & $\begin{array}{c}\text { 305d MY } \\
(\mathrm{kg})\end{array}$ & TMY (kg) & LP (day) & $\begin{array}{c}305 d \mathrm{MY} \\
(\mathrm{kg})\end{array}$ & TMY (kg) & LP (day) \\
\hline Maximum & & & & & & \\
\hline CBW & 49.90 & 15.75 & 8.62 & 130.08 & 17.02 & 15.80 \\
\hline Standard error & 0.86 & 0.66 & 0.65 & 2.91 & 1.38 & 1.63 \\
\hline Accuracy & 0.71 & 0.72 & 0.87 & 0.70 & 0.69 & 0.73 \\
\hline Minimum & & & & & & \\
\hline CBW & -13.42 & -29.69 & -12.89 & -65.04 & -12.86 & -37.36 \\
\hline Standard error & 0.81 & 0.66 & 0.58 & 2.64 & 1.21 & 1.72 \\
\hline Accuracy & 0.74 & 0.73 & 0.91 & 0.76 & 0.77 & 0.69 \\
\hline Range $\left(\mathrm{CBW}^{\mathrm{Max}}-\mathrm{CBW}^{\mathrm{Min}}\right)$ & 63.32 & 45.44 & 21.51 & 195.12 & 29.88 & 53.16 \\
\hline
\end{tabular}

Table 7. The predicted all Sire breeding values (SBV) for milk traits in Friesian cows in Sakha and Ghrbawy herds .

\begin{tabular}{|c|c|c|c|c|c|c|}
\hline & \multicolumn{3}{|c|}{ SF } & \multicolumn{3}{|c|}{ GF } \\
\hline & $\begin{array}{c}305 d- \\
\text { MY (kg) }\end{array}$ & TMY (kg) & LP (day) & $\begin{array}{c}\text { 305d MY } \\
(\mathrm{kg})\end{array}$ & TMY (kg) & LP (day) \\
\hline Maximum & & & & & & \\
\hline SBW & 23.25 & 15.70 & 15.24 & 102.60 & 11.32 & 8.66 \\
\hline Standard error & 0.75 & 0.66 & 1.14 & 1.95 & 1.95 & 1.77 \\
\hline Accuracy & 0.78 & 0.72 & 0.47 & 0.88 & 0.89 & 0.67 \\
\hline Minimum & & & & & & \\
\hline SBW & -26.79 & -11.67 & -27.04 & -47.50 & -8.72 & -22.04 \\
\hline Standard error & 0.83 & 0.64 & 1.15 & 3.02 & 1.40 & 1.48 \\
\hline Accuracy & 0.73 & 0.74 & 0.47 & 0.67 & 0.68 & 0.78 \\
\hline Range(SBW $\left.{ }^{\text {Max }}-S^{S B W^{M i n}}\right)$ & 50.04 & 27.37 & 42.24 & 150.1 & 20.04 & 30.70 \\
\hline
\end{tabular}

Table 8. The predicted all Dam breeding values (DBV) for milk traits in Friesian cows in Sakha and Ghrbawy herds.

\begin{tabular}{|c|c|c|c|c|c|c|}
\hline & \multicolumn{3}{|c|}{ SF } & \multicolumn{3}{|c|}{ GF } \\
\hline & $\begin{array}{c}\text { 305d- MY } \\
(\mathrm{kg})\end{array}$ & TMY (kg) & LP (day) & $\begin{array}{c}\text { 305d MY } \\
(\mathrm{kg})\end{array}$ & TMY (kg) & $\begin{array}{c}\text { LP } \\
\text { (day) }\end{array}$ \\
\hline Maximum & & & & & & \\
\hline DBW & 26.69 & 15.49 & 16.24 & 59.93 & 12.09 & 15,56 \\
\hline Standard error & 0.86 & 0.66 & 1.14 & 2.69 & 1.20 & 1.53 \\
\hline Accuracy & 0.70 & 0.72 & 0.48 & 0.75 & 0.78 & 0.77 \\
\hline Minimum & & & & & & \\
\hline DBW & -30.26 & -13.88 & -29.96 & -59.50 & -12.56 & -20.91 \\
\hline Standard error & 0.90 & 0.64 & 1.14 & 2.46 & 1.15 & 1.61 \\
\hline Accuracy & 0.66 & 0.75 & 0.48 & 0.80 & 0.80 & 0.74 \\
\hline Range(DBW $\left.{ }^{M a x}-D^{-} W^{M i n}\right)$ & 56.95 & 29.37 & 46.20 & 119.43 & 24.65 & 36.47 \\
\hline
\end{tabular}




\section{CONCLUSION}

Results of the present study indicated that non genetic factors (parity, season of calving, year of calving) were found to have a significant $(P<0.01)$ effects on milk production traits. The results also showed that heritability estimates for 305d MY trait of cows in Ghrbawy farm (commercial) were less than that of cows in Sakha farm(state) while, it was greater for LP and TMY traits of Ghrbawy cows.

In the commercial farm (GF), it was found that low negative genetic trends in sires for the studied traits were expected due to the absence of a long term selection plan for sires. On the other side, long term selection program of cows to improve milk production and fertility of cows would be beneficial in the commercial herd. In addition, planned mating with semen of proven sires which possess high potential for milk production would be effective to increase milk traits in such herds.

The ranges of breeding values for cows were higher than those for dams or sires for milk traits. It could be stated that selecting cows for milk production traits according to their breeding values would be more reasonable and efficient than selecting cows according to sires or dams breeding values in both farms.

It can be concluded that improving environmental conditions and management practices, coupled with improved genetic potential of dairy animals in the state or commercial farms would be more effective approaches for high milk productivity.

\section{ACKNOWLEDGEMENTS}

My deepest thanks and acknowledgements are extended to Mahmoud Gharib Ph.D. of Animal breeding , Animal production research Institute at Dokkifor his kind help on analysis of data. Also, deep gratitude to Gharbawy farm members for their sincere during data collection .

\section{REFERENCES}

1. Abdel-Gader AZ, Khair M, Ahmed A, Lutfi MA, Peters KJ. 2007. Milk yield and reproductive performance of Friesian cows under Sudan tropical conditions. Arch Tierz Dum. 50:155-164.

2. Afifi ,E. A., Khalil, M.H., Arafa Samira A. and Salem, M.A. 2002. Estimation of transmitting abilities for lactation traits using the animal model for Holstein cattle raised under a commercial farm in Egypt . J. Agric. Sci., Mansoura Univ., 27 (1) : 89-97.

3. Allam, A.A.F. 2011. Evaluation of productive and reproductive performance of Friesian cattle under Egyptian condition. M.Sc. Thesis, Fac. Of Agric. Damanhur Univ.Egypt

4. Amr .M . A. 2013. Evaluation of performance of some dairy herds in Egypt PhD .Thesis Face .Agaric . Alexandria Universe . Egypt

5. Boldman, K.G., Kriese, L.A., Van Vleck, L.D., Van Tassell, C.P. and Kachman, S.D., 1995. A manual for the use of MTDFREML.ARS, USDA, Clay Center, N.E., USA. 
6. Bugeac T, Maciuc V, Creangă Ş.T. 2013. Genetic parameters of milk yield and quality traits in Holstein-Friesian cows. Bulletin UASVM Anim. Sci. Bio. 2013;70:150-154.

7. El-Arian M.N, Shalaby NA. 2001. Genetic analysis for lactation curve traits and persistency indices of Friesian cattle in Egypt. J AgricSci Mans Univ. 26:19571973.

8. El-Attar, S.M. 2009. Breeding value of Holstein-Friesian cattle in Egypt. M.SC.Thesis. Fac. Of Agric.Alex .Univ. Egypt .

9. Faid-Allah, E. 2015. Genetic and Non-Genetic Analysis for Milk Production and Reproductive Traits in Holstein Cattle in Egypt .JITV Vol. 20 No 1 Th. 2015: 10-17

10. Gabr, A.A. 2005. Evaluation of some economic traits of Friesian cows in Egypt .M.Sc. Thesis, Fac . Agric. Mansoura Univ. Egypt .

11. Hammami, H., B. Rekik, H. Soyeurt, C. Bastin, J. Stoll and Gengler, N. 2008. Genotype environment interaction for milk yield in Holstein is using Luxembourg and Tunisian populations . J. Dairy Sic . 91:3661-36671.

12. Hammoud MH. 2013. Genetic aspects of some first lactation traits of Holstein cows in Egypt. Alex J Agric Res. 58:295-300.

13. Javed K, Afzal M, Sattar A, Mirza RH. 2004. Environmental factors affecting milk yield in Friesian cows in Punjab, Pakistan. Pak Vet J. 24:58-61.

14. Lakshmi, B. S, Gupta,B. R. Sudhakar, K. Prakash, M. G. and Sharma, S. (2009).Genetic analysis of production performance of 642 Holstein Friesian $\times$ Sahiwal cows. Tamilnadu J Vet \& AnimSci 5(4): 143-148.

15. Mostafa, M. A. ;Enas A. Bader and khattab, A. S. 2013. variances of direct and maternal genetic effects for milk yield and its composition in a herd of Friesian cows in Egypt J. Animal and Poultry Prod., Mansoura Univ., Vol.4 (8): 493 - 499

16. Mustafa, T. and Serdar, K. 2009). Relationship between production and fertility traits in first lactation and lifetime performance of Holstein cows under subtropical condition. Arch. Tierzcht . 52 (4) : 364-370.

17. Taha, M. H. H. 2013. Genetic studies on dairy cattle in Egypt. Ph.D. Thesis .Fac .Agric . Mansoura Univ. Egypt .

18. [SAS]. 2003. Statistical Analysis System: User's guide (Ver 9). North Carolina (US): SAS Institute Inc., Cary.

19. Usman. T., G.Guo ,S.M.Suhail , Ahmed, S. Qiaoxiang , L. Qureshi , M. S. and Wang, Y. 2012. Performance traits study of Holstein Friesian cattle under subtropical conditions The Journal of Animal and Plant Sciences, 22(2 Suppl.):, Page: 92-95 ISSN: 1018-7081 .

20. Usman T, Guo G, Suhail SM, Ahmed S, Qiaoxiang L, Qureshi MS, Wang Y. 2011. Performance traits study of Holstein Friesian cattle under subtropical conditions. J Anima Plant Sci. 21:961. 


\title{
مقارنة المعالم الور اثية لصفات انتاج اللبن الفريزيان

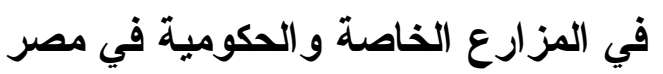

\author{
صفاء سند و احمد عفيفي
}

معه بحوث الاتتاج الحيواني ، مركز البحوث الزراعية ، وزارة الزراعة ، الدقي ، مصر .

في هذه الدراسة تم عمل مقارنة من الناحية الور اثية بين مزرعتي سخا و الغرباوي أحدهما

$$
\text { تجاري (الغرباوي) و الاخر حكومي (سخا) . }
$$

اجريت هذه الدراسة على عدد رب؟ ا سجل لقطيع ابقار فريزيان (مزرعة حكومية) خلال

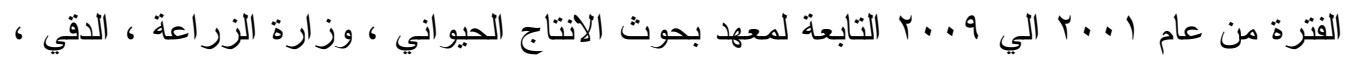

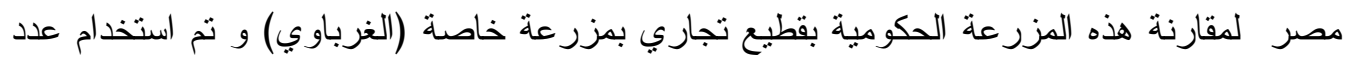

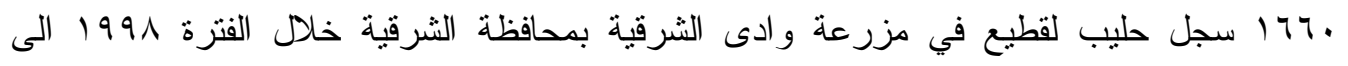
O...

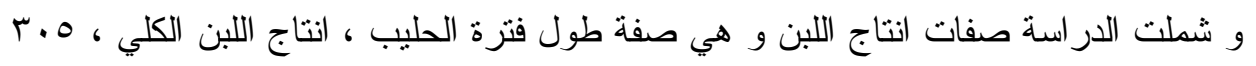
يوم انتاج لبن و دراسة اهم العو امل الغير وراثية ، العوامل الوراثية و كذللك تقييم القيم التزبوية لصفات انتاج اللبن

باستخدام تحليل البيانات نموذج الحيوان بطريقة MTDFREML ( 1995 ) وتضمن النموذج

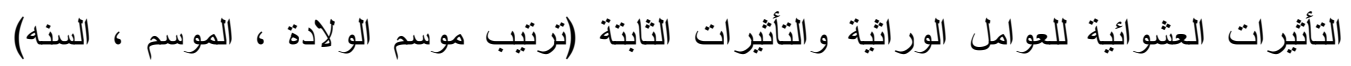
لحساب المكافئات الور اثية والقيم المتوقعة للقيم التزبوية لكل صفة وكذللك للارتباط الوراثي بين الصفات المختلفة حيث كان لسنة الولادة تأثثير عالي المعنوية على صفات الدراسة (طول فترة لكنة

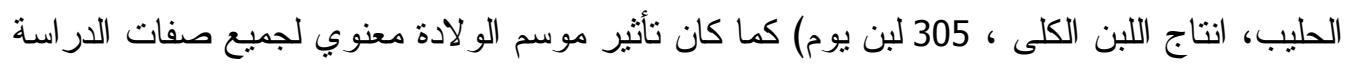

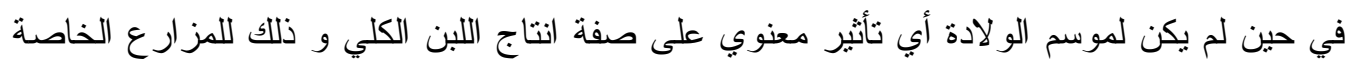

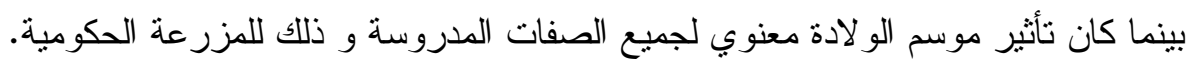

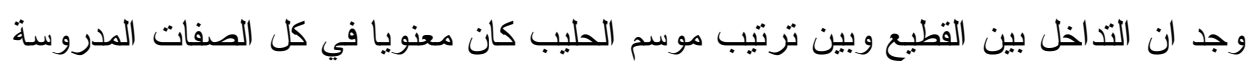

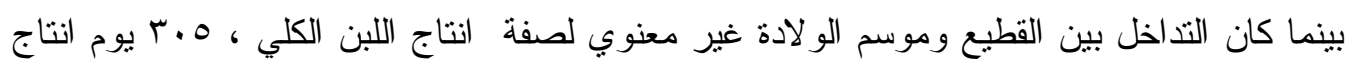

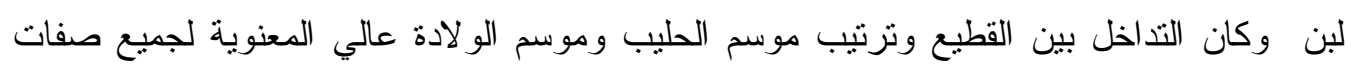
الدر اسة .

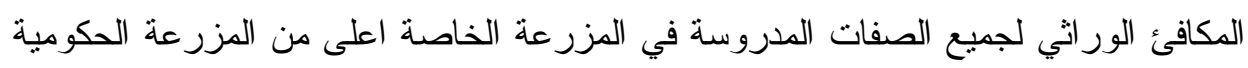

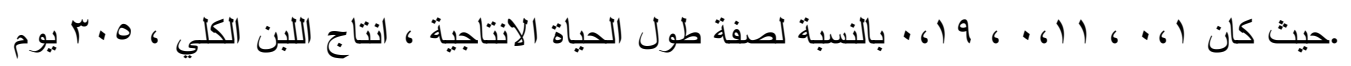

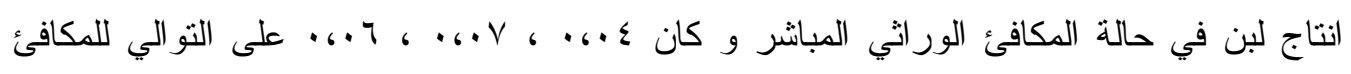

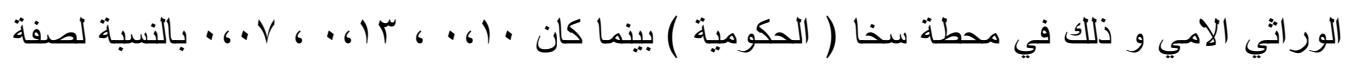

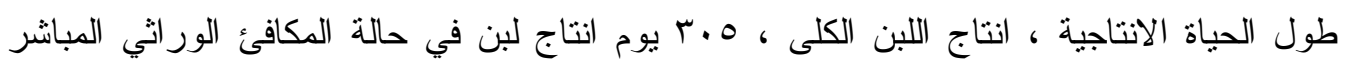




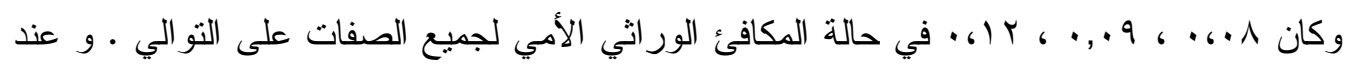

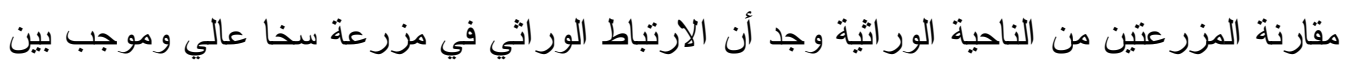

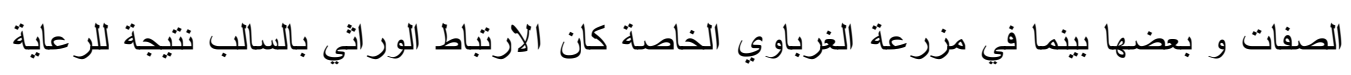
وبمقارنه القيمة التربوية لإنتاج اللبن للصفات المدروسة للمزرعتين وجد ان القيم التربوية للغرباوي

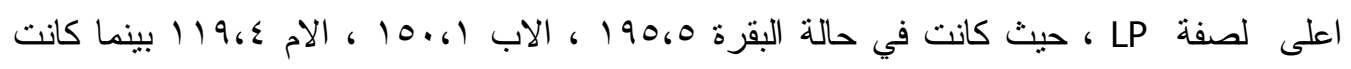

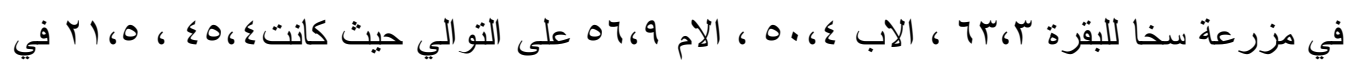

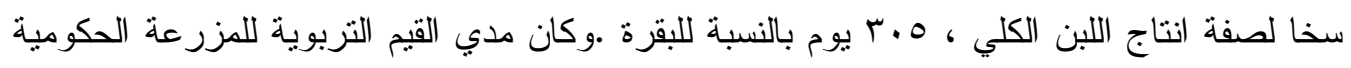

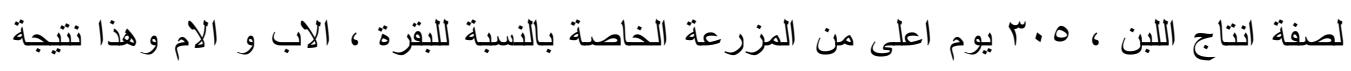

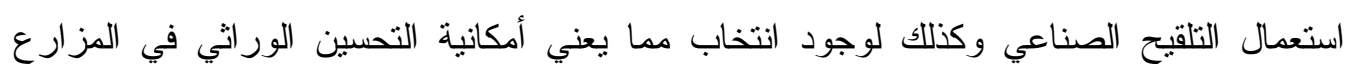
الخاصة عن طريق الانتخاب واستعمال التلقيح الصناعي .

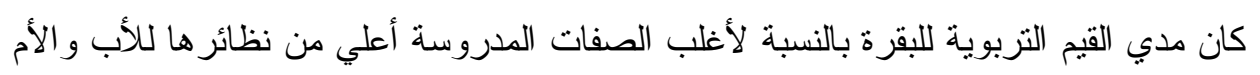

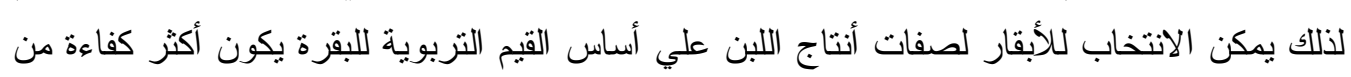

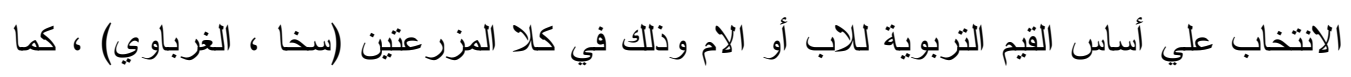

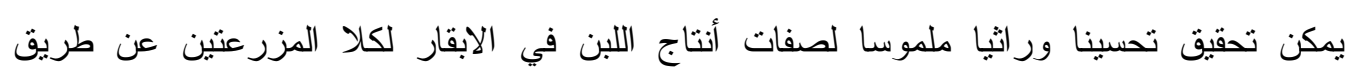

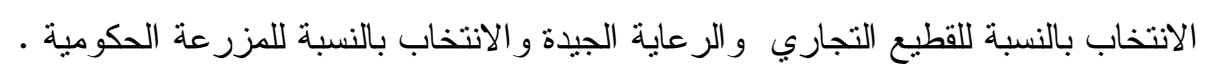

